\title{
The Florentine art of cartography: Rosselli's 'Fiorenza' and early map printing in the Italian Renaissance
}

\author{
Zsolt Győző Török \\ Institute of Cartography and Geoinformatics, ELTE Eötvös Loránd University, Budapest, Hungary, zoltorok@map.elte.hu
}

Keywords: Renaissance art, map printing, city view, Francesco Rosselli, commercial cartography

\begin{abstract}
:
The first Renaissance printing workshop, specializing in cartography was established in the 1480s by Francesco Rosselli in Florence. This paper reconsiders his maps and views in the context of Renaissance cosmography and copper plate engraving and printing to reconstruct an ambitious and carefully designed publishing programme, which substantially influenced later Italian commercial cartography. Rosselli's large view of his home city, his Fiorenza, was arguably his first independent cartographic project, and this first modern city view became a prototype and a highly successful product representing a new cartographic genre.
\end{abstract}

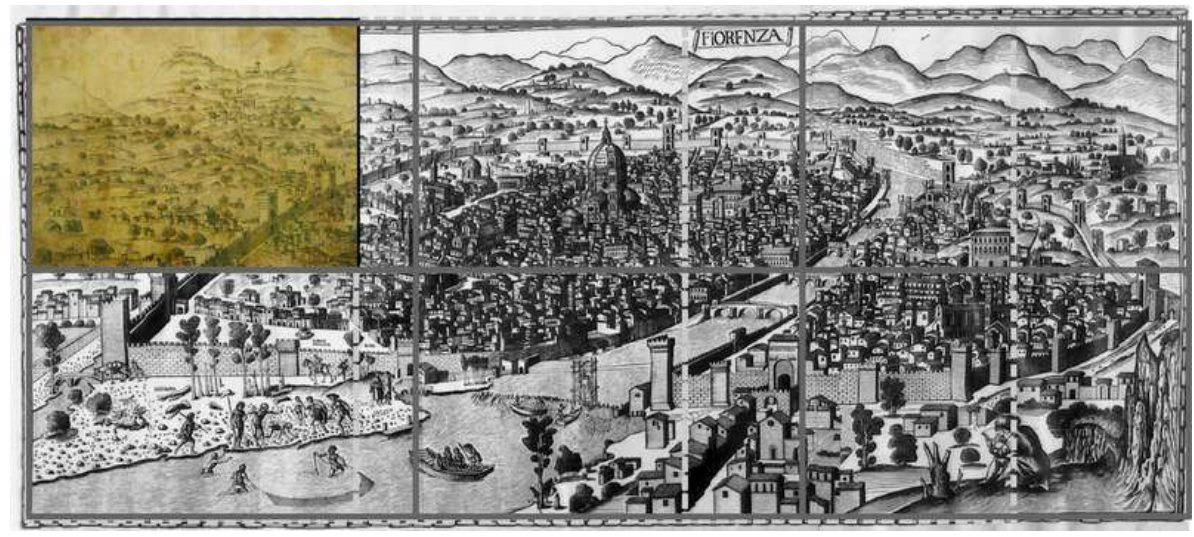

Figure 1. The reconstruction of Rosselli's six-sheet view of Florence (c. 1485) with the survived fragment based on the eight-sheet (indicated by dashed lines) woodcut edition attributed to Lucantonio Uberti (c.1510, Venice)

Printing maps was the most influential innovation in early modern cartography, which made a large number of cartographic images available on the market for the common people. The first printed maps that appeared in the late 15 th century revolutionized not only the ways how geographical pictures were produced, but the new patterns of their distribution and consumption also had a substantial influence on the use of maps in early modern European societies. The very first examples of reproduction, the TO-diagram in Isidorus' Etymologiarum ... (1472, Augsburg) or the maps in the Rudimentum Novitiarum (1475, Lübeck) were woodcut illustrations in printed books.

For his significant role in the early history of the printed image, Francesco's name became known to art historians only in the 20th century. His artistic works, especially his early engravings, were not identified by historians of art before the discovery of one of his major cartographic achievements, the now-famous Contarini-Rosselli world map (1506) preserved in the British Library, London. The attitude changed by the end of the century, and in recent publications, Rosselli has already been regarded as the leading engraver of late fifteenth-century Florence. The 1527 inventory of the Rosselli workshop in the Archivio di Stato di Firenze (and first published in 1894), is a highly important documentary source about a Renaissance print shop and offers insight into the publishing programme as well as the market for maps. The inventory was first taken in 1526, after the death of Francesco's son, Allesandro. The legal document recorded various items found in the workshop, most importantly a valuable list of woodblocks and printing plates. Although the shorts notes of the notary are sometimes rather obscure, in most of the cases the subject of the print is given. Based on these working titles modern researchers could identify most of the plates with actual, preserved Florentine prints from the period c. 1490 1520 as works from Francesco Rosselli's workshop. The remarkable fact is that about half of the altogether 79 printing forms (including 49 copper plates) were not depictions of religious imagery, but cartographic works. The 20 cartographic items included seven, different size world maps and at least four, multi sheets, large city views (Pisa, Rome, Constantinople and Florence). This aspect makes the Rosselli inventory the testimony of the existence of the first commercial cartographic enterprise in Renaissance Europe and its publishing programme. 
The name of the Rosselli family is not unknown to historians of Renaissance art: the vita of the Florentine painter Cosimo Rosselli, who painted frescos in the Sistine Chapel in Rome, was included in Vasari's Lives. The life of Francesco, the younger step-brother who was born ca. 1448, is poorly documented. The earliest record mentioning the brothers is from the 1470s when Francesco worked as a miniaturist and illustrated choir books for Siena's cathedral library. From around 1480, in a tax record submitted by Cosimo, it was mentioned that at that time Francesco with no property was in Buda, Hungary. In the court of King Matthias Corvinus, with other Italian artists, he illuminated manuscripts for the Bibliotheca Corviniana. Rosselli's decorative style can be identified in many codices, including milestone works of Renaissance astronomy and geography. From a cartographic point of view, the most remarkable illuminated volumes related to the Rosselli workshop are the splendid copies of Ptolemy's Geographia. This may indicate his growing personal interest in cosmographical subjects. Around 1482 Francesco returned from Hungary, and bought a house in Florence and acquired other properties. As his financial situation had improved, he could set up his printing workshop. Along with religious and decorative prints, the reproductive engraver innovatively created prototypes for the first printed maps of the world, countries, and cities and begin his own Renaissance cosmographical publishing project.

Possibly Francesco was involved earlier in the Florentine publication of Francesco Berlinghieri's edition of Ptolemy. Both stylistic and circumstantial evidence shows that he was one of the engravers of the thirty-one copper plates for the maps. However, these were produced by the traditional Italian engraving tools of the niello-making goldsmith. However, Rosselli's works after his return from Buda suggest his adoption of a new technique along with the use of the lozengeshaped burin. The new tool in the engraver's hand was especially suitable for the reproduction of graphic works consisting of long, curved lines with various thickness (Broad manner), first of all, geographical maps.

In the 1880s a unique view of Florence was discovered in Berlin: the work since called the Pianta della Catena, or "Chain View of Florence", because of the chain motif that runs around the image. The undated woodcut on eight sheets is not signed, and no information is given in the printed image regarding its makers or the place where it was printed. Scholars considered the woodcut as the work of Lucantonio Uberti. The opinion was grounded on the Florentine style of woodcut, and on the fact that Uberti was a local engraver who learned the woodcut technique and was active in Venice until 1516. New research revealed that Uberti, like Rosselli, also worked in Hungary as a printmaker. In 1911 it was suggested that the designer of the original image was Francesco Rosselli. The list of the printing plates in his workshop's inventory actually includes item no. 63, 'Firenze di sei fogli reali', which could well be the model for the Chain View.

Only a fragment of this earlier view, engraved by Francesco Rosselli into copper in fifteenth century, has survived. The representation of the prominent buildings in the engraved fragment suggests the view was made in the second half of the 1480s. The woodcut view of Florence in the Nuremberg Chronicle was based on this engraving, and therefore it was a certainty that Rosselli's work was printed earlier than 1493. The date of its printing was before 1490, because in that year a small, derivative view of Florence appeared in Foresti's printed world chronicle.

Comparison of the engraved fragment with the woodcut view shows the woodcut is a close copy of the original, although not without differences and errors. The inscriptions in the woodcut are in Venetian dialect, three churches and their names are missing, and there are several misspellings as well. The mountain range behind Fiesole, most likely Monte Giovio, is missing from the woodcut. Contrary to the engraved fragment, the woodcut is framed with the chain and the lock. The figural scene at the river Arno, related to Savonarola's execution, was not part of the original view. The view in Schedel's Chronicle (1493) and the ca. 1495 painting attributed to Rosselli (VAM, London) suggests that Rosselli's view included figural scenes.

Although at first sight, the view designed by Francesco Rosselli may seem to be a modern, perspective view, the image is a transitional product from the medieval picture map to the modern map. The cupola of the Duomo is much taller than it should be and the lantern is carefully placed above the city wall. The suggested point of view of the reader is also problematic, as it is a combination of multi-point perspective. The scene with Fiesole on top of a hill is close to the actual spectacle from the Oltrarno, while the drawing figure suggests the artist view from the top of Monte Oliveto. In other words, the general organization of the view is not purely geometrical, but rather intellectual and interpretive.

\section{References:}

Almagià, R. (1951). On the Cartographic Work of Francesco Rosselli. Imago Mundi, 8, 27-34.

Banfi, F. (1940) Franceso Rosselli térképész Mátyás király udvarában”, Térképészeti Közlemények, 6, 91-107.

Boorsch, S. (2004). The Case for Francesco Rosselli as the Engraver of Berlinghieri's Geographia", Imago Mundi, 66, $152-169$.

Hind, A. (1938) Early Italian Engraving. London.

Robert, S. (2011). Francesco Roselli and Berlinghieri’s Geographia Revisited. Print Quarterly 28 (1) 4-17.

Török, Z.G. (2013). Artist and Cosmographer: Francisco Rosselli and his Fiorenza. in: Israëls, M. -Waldman, L.A.

(eds.) Renaissance Studies in Honor of Joseph Connors. Villa i Tatti Series 29, Harvard Univ. Press, 161-168. 